\title{
High susceptibility to collagen-induced arthritis in mice with progesterone receptors selectively inhibited in osteoprogenitor cells
}

\author{
Lixian Liu ${ }^{1 \dagger}$, Junjing Jia ${ }^{1,2+}$, Min Jiang ${ }^{1}$, Xueping Liu ${ }^{1}$, Chenling Dai ${ }^{1}$, Barton L. Wise ${ }^{1,3}$, Nancy E. Lane ${ }^{1}$ \\ and Wei $\mathrm{YaO}^{1 *}$ (i)
}

\begin{abstract}
Background: Progesterone receptor (PR) affects immunomodulation, and lack of PR in osteoprogenitor cells primarily affects pathways associated with immunomodulation, especially in males. In this study, we selectively deleted PR from osteoprogenitor cells using Prx1-Cre to evaluate the tissue-specific effects of PR on the pathegenesis of inflammatary arthritis (IA).

Methods: Collagen-induced arthritis (CIA) was used as an IA animal model. Both male and female PR ${ }^{\Delta \mathrm{Prx} I}$ mice and their wild-type (WT) littermates were immunized with collagen II (CII) emulsified complete Freund's adjuvant (CFA). Joint erosion, inflammation, and cartilage damage were assessed using a semiquantitative histologic scoring system. Bone volume and erosions in knee and ankle joints were quantitated using microCT and histology.

Results: Bone erosions developed in both paw joints in $37.5 \%$ and $41.7 \%$ of the $W T$ and $P R^{\Delta P \times 1}$ female mice and in 45.4 and $83.3 \%$ of the $W T$ and $P R^{\Delta P r x 1}$ male mice, respectively. Also, both joint damage and subchondral bone erosions were significantly more severe in male PRcKO-CIA mice than in male WT-CIA mice. Female PR ${ }^{\Delta \mathrm{Prx} 1}$ mice also developed higher bone loss in the knee joints than the KO-normal or WT-CIA females although with less severity compared to the male mice.
\end{abstract}

Conclusions: The presence of PR in osteoprogenitor cells decreased the development of collagen-induced arthritis and might help to explain the sex differences observed in human inflammatory arthritis.

Keywords: Progesterone receptor, Inflammatory arthritis, Osteoprogenitor cells, Susceptibility, Sex difference

\section{Introduction}

Rheumatoid arthritis (RA) is a systemic autoimmune disease that can affect many organ systems, and inflammation of synovial tissue causes activation of inflammatory cytokines that destroy both cartilage and periarticular

\footnotetext{
* Correspondence: wy5997686@gmail.com

${ }^{\dagger}$ Lixian Liu and Junjing Jia contributed equally to this work.

'Department of Internal Medicine, University of California, Davis Medical Center, 4625 2nd Avenue, Sacramento, CA 95817, USA

Full list of author information is available at the end of the article
}

bone [1-3]. About 3 million Americans suffer from RA, with nearly three times more women than men affected [4-8]. In women, RA most commonly begins between the ages of 30 and 60 years, but in men, RA often begins later in life. The mechanism for this sexual dimorphism in RA is not clear. Most studies of sex-specific factors affecting RA have focused on sex hormones due to the observation that RA activity is reduced in females during pregnancy and that male RA patients generally have a less severe course of disease and better response to

C C The Author(s). 2020 Open Access This article is licensed under a Creative Commons Attribution 4.0 International License, which permits use, sharing, adaptation, distribution and reproduction in any medium or format, as long as you give appropriate credit to the original author(s) and the source, provide a link to the Creative Commons licence, and indicate if changes were made. The images or other third party material in this article are included in the article's Creative Commons licence, unless indicated otherwise in a credit line to the material. If material is not included in the article's Creative Commons licence and your intended use is not permitted by statutory regulation or exceeds the permitted use, you will need to obtain permission directly from the copyright holder. To view a copy of this licence, visit http://creativecommons.org/licenses/by/4.0/ The Creative Commons Public Domain Dedication waiver (http://creativecommons.org/publicdomain/zero/1.0/) applies to the data made available in this article, unless otherwise stated in a credit line to the data. 
therapy $[5,9,10]$. Estrogen is reported to have both proinflammatory and anti-inflammatory effects on the immune system while both progesterone and androgen are anti-inflammatory [11-19]. The effects of hormones are primarily regulated through their hormonal receptors. The presence and proportion of hormone receptors in different tissues and cells, including fibroblasts, chondrocytes, and bone cells, may define their roles in the sexually dimorphic pathogenesis of RA [20-27].

\section{Potential effects of progesterone on arthritis}

Progesterone is a sex-related steroid that has been studied extensively for its effects on the reproductive system. Progesterone's actions are mainly mediated through the progesterone nuclear receptors A and B (PR-A and B), which are ligand-regulated transcription factors [28]. The presence or absence or relative proportion of PR in different tissues may explain the PR's sexual dimorphic roles in these tissues [29-31]. In contrast to the estrogen receptor, PR's role may be more important in immunomodulation in female-dominant diseases such as systemic lupus erythematosus, rheumatoid arthritis, and osteoarthritis [32-34]. However, the immunomodulatory role of PR in musculoskeletal tissue is not well understood. PR is expressed by cultured osteoblasts, osteoclasts [35-37], and chondrocytes [38] and is present in vivo in mouse bone [37, 39]. Utilizing genetic fate mapping and immunohistochemistry techniques, we observed PR (esp. PR-B) expression in articular cartilage and in the growth plate as well as in subchondral bone [39]. We also noted that in PR selective deletion in Prx1+ cells, which give rise to both osteoblasts and chondrocytes, the $\mathrm{PR}^{\Delta \mathrm{Prx} 1}$ mice had significantly higher trabecular bone mass as compared to their WT littermates [39]. Additionally, conditional PR deletion in the Prx1+ osteoprogenitor cells significantly suppressed immunomodulatory pathways, especially in the males. The disease pathway analyses and RNA-Seq study suggested that rheumatoid arthritis is a potential disease target for PR modulation [34]. Since the lack of PR signaling in the osteoprogenitor cells (OPC) regulated immunomodulation pathways [34], we performed this study to evaluate the role of $\mathrm{PR}$ in the $\mathrm{PR}^{\Delta \mathrm{Prx} 1}$ mice using a CIA model.

\section{Methods}

\section{Mice and collagen-induced arthritis (CIA) model}

PR-flox mice were obtained from Baylor College of Medicine (Houston, TX, USA). A targeting vector designed to replace part of exon 2 of the PR gene with a selectable marker was employed to create a strain of mice carrying a conditional null PR allele [40]. Prx1-Cre mice were purchased from the Jackson Laboratory. Eight-week-old female and male mice were immunized with $100 \mu \mathrm{g}$ chicken collagen in completed Freund's adjuvant (CFA) (Chondrex Inc. Redmond WA USA). On day 21 , the mice were boosted with $100 \mu \mathrm{g}$ chicken collagen in in-completed Freund's adjuvant (IFA) subcutaneously. On day 24, all mice received $50 \mu \mathrm{g}$ LPS E. coli O111: B4 (Sigma St. Louis, MI USA) via intraperitoneal injection (i.p.) in normal saline. The mice were euthanized on day 50 . The onset of the CIA usually occurs on day 26, after initial immunization, and the disease model generally lasts 40 days [41-45].

PCR-based strategies were used for genotyping mouse genomic DNA. All animal work was done in compliance with the guiding principles of UC Davis's "Care and Use of Animals." Mice were housed in the animal facility under strictly controlled environmental conditions (12-h light/dark cycle, room temperature $22^{\circ} \mathrm{C}$ ), and fed ad libitum (food and water). The Institutional Animal Care and Use Committee of the University of California Davis approved the animal protocol.

\section{T cell stimulation for FACS}

Total mononuclear cells were collected from peripheral blood using the Ficoll-Paque density gradient method. The cells were then incubated with phorbol 12-myristate 13-acetate (PMA) in combination with ionomycin for 3 days before running fluorescence-activated cell sorting (FACS). We used the following key markers for activated $\mathrm{T}$ cells CD3/PerCP-Cy5.5 (Total T), CD25/PE-CF594, and CD45RO/PE-Cy7 ( $\mathrm{R} \& \mathrm{D}$ Systems, Minneapolis, MN, USA).

\section{Measurements of inflammation, bone erosion, and cartilage damage}

Whole knee and ankle joints were fixed, decalcified, embedded in paraffin, and stained with hematoxylin or Safranin-O. Inflammation was scored semi-quantitatively from 0 to 5: $0=$ normal; $1=$ minimal infiltration of inflammatory cells and/or mild edema; $3=$ moderate infiltration; 4 =marked infiltration; and $5=$ severe infiltration. For bone erosion, joint sections were stained for tartrate-resistant acid phosphatase (TRAP) and counterstained with hematoxylin (Sigma St Louis, IL, USA). A score of $0-5$ was assigned for bone erosion: $0=$ normal; $1=$ minimal (small areas of bone resorption, not readily apparent on low magnification); $2=$ mild (more areas of resorption in trabecular and cortical bone); $3=$ moderate (obvious bone resorption of trabecular and cortical bone, without defects in cortex or loss of trabeculae); $4=$ marked (full-thickness defects in cortical bone and marked trabecular bone loss); and $5=$ severe (defects in the entire cortex, marked trabecular bone loss) [46-48]. Total TRAP+ cells within the subchondral area were counted and presented as TRAP+ cell/bone surface. Cartilage damage was calculated by the loss of Safranin-O staining that was scored on a semi- 
quantitative scale from 0 to $4: 0=$ intact; $1=\operatorname{minor}(<$ $10 \%) ; 2=$ moderate $(10-50 \%) ; 3=$ high $(50-80 \%) ;$ and $4=$ severe $(80-100 \%)[49,50]$. Two blinded observers performed all the scorings. Data are presented as the average of the scores of both observers.

\section{Bone mass measurements by microCT}

The right knee joints including both the distal femurs (DFM) and the proximal tibiae were scanned and analyzed using VivaCT 40 (Scanco Medical, Bassersdorf, Switzerland) with a voxel resolution of $10 \mu \mathrm{m}$ in all three spatial dimensions and a mono-energetic $(70 \mathrm{Kev}) \mathrm{X}$-ray source. We evaluated the entire knee covering a total of $645 \mathrm{~mm}$ in length centered around the knee joint to obtain total knee bone volume/tissue volume (BV/TV) ratio [34, 51, 52] using 3D image-registration schemes Gaussian filters of sigma $=0.8$, support $=1$, and threshold $=180$ for total knee and DFM. Gaussian filters of sigma $=1$, support $=2$, and threshold $=280$ were applied to register the paw.

\section{Knee histopathology}

The left knee joints were fixed in 10\% phosphatebuffered saline formalin for 2 days, decalcified in $10 \%$ EDTA for 3 weeks, and embedded in paraffin. Sections were stained with Safranin-O-Fast green for measurement of articular cartilage thickness, subchondral bone plate thickness, subchondral trabecular bone number and diameter, and cartilage content using Bioquant Imaging software (Bioquant Imaging System, Nashville, VA USA) [51, 52].

\section{Statistical analysis}

The results are expressed as mean \pm standard deviation for bone structure measures, bone turnover, and bone strength variables. Two-way ANOVA was used to account for genotype and sex. If significant differences were observed, then a Sidak's multiple comparisons test was used to assess pairwise comparisons. A value of $p<0.05$ was considered statistically significant. Data were analyzed using the GraphPad Prism 8 software package (La Jolla, CA, USA).

\section{Results}

Mice with PR conditionally knocked out in osteoprogenitor cells (OPC) had higher systemic activation of $T$ cells and showed higher incidence of arthritis

We found very low levels of circulating activated $\mathrm{T}$ cells marked by CD3e+, CD69+, and CD25+ in the WT-CIA controls, especially in the female WT-CIA mice, at proximately $0.1 \%$ of the total mononuclear cells. On the other hand, both female and male $\mathrm{PR}^{\Delta \text { Prx1 }}$-CIA mice had significantly higher circulating levels of activated $\mathrm{T}$ cells as compared to the WT-CIA mice at day 50 (Fig. 1a).
The incidence of arthritis (defined as developing bone erosions viewed by 3D microCT reconstructions of paw images) was $37.5 \%$ and $41.7 \%$, respectively, in the female WT and $\mathrm{PR}^{\Delta \operatorname{Prx} 1}$-CIA mice and 45.4 and $83.3 \%$, respectively, in the male $\mathrm{WT}$ and $\mathrm{PR}^{\mathrm{APrx}}$-CIA mice (Fig. $1 \mathrm{~b}$ ). Hence, we observed an increase in systemic inflammation and development of arthritis in the paws in mice lacking PR in the MSCs, highlighting a possible role of $\mathrm{PR}$ in systemic as well as local tissue involvement during inflammatory arthritis.

\section{$\mathrm{PR}^{\Delta \mathrm{Prx} 1}$ mice with collagen-induced arthritis had higher levels of bone destruction}

MicroCT and histochemical analyses were used to assess the degree of bone erosion in the ankle and the knee joints in WT-CIA and $\mathrm{PR}^{\Delta \text { Prxi }}$-CIA mice and the control mice which did not receive immunizations. In the paws, total bone volume did not differ in WT-CIA mice compared to their WT-non-CIA controls, but was reduced significantly in male $\mathrm{PR}^{\Delta \mathrm{Prx} 1}$-CIA mice compared to the $\mathrm{PR}^{\triangle \operatorname{Prx} 1}$-non-CIA male controls (Fig. 2a). Areas of bone erosion were present on microCT images of paws, especially in the distal and proximal ends of the metacarpus as well as in the carpus, in the male WT-CIA and $\mathrm{PR}^{\Delta \operatorname{Prx} 1}$-CIA mice (Fig. 2b, white arrows). Compared to the non-CIA mice, female $\mathrm{PR}^{\Delta \mathrm{Prx} 1}$-CIA, male WT-CIA, and male $\mathrm{PR}^{\triangle \mathrm{Prx} 1}$-CIA mice had reduced total bone volume in knee joints. The female $\mathrm{PR}^{\triangle \mathrm{Prx} 1}$-CIA had significantly higher bone loss in the knee joint compared to the female WT-CIA mice (Fig. 3a). The non-CIA $\mathrm{PR}^{\triangle \mathrm{Prx} 1}$ mice had smooth and continuous bone surfaces in their knees, while focal peri-articular bone erosions were apparent in both the female and male $\mathrm{PR}^{\Delta \mathrm{Prx} 1}$-CIA mice (Fig. 3b, white arrows). Histologic measurements confirmed the absence of trabecular bone loss at the femoral subchondral bone in the female and male WTCIA mice (Fig. 4a-c). Both female and male $\mathrm{PR}^{\triangle \mathrm{Prx}}$ CIA mice had lower trabecular bone volume compared to their sex-matched $\mathrm{PR}^{\Delta \mathrm{Prx} 1}$-non-CIA and WT-CIA mice, with similar subchondral cortical bone plate thickness across all the groups (Fig. 4c). TRAP histochemistry was used to determine the numbers of osteoclasts at the distal femurs, with a focus on the subchondral bone erosions. TRAP+ cell numbers were similar in female and male WT-CIA mice compared to their WT-normal controls. The female $\mathrm{PR}^{\triangle \mathrm{Prx} 1}$-CIA mice had a trend of increased TRAP+ cells in the subchondral bone area but did not reach statistical significance when compared to $\mathrm{PR}^{\Delta \mathrm{Prx} 1}$-normal control mice. In contrast, more TRAP+ cells were present on the femoral subchondral trabecular bone surface in the male $\mathrm{PR}^{\triangle \mathrm{Prx} 1}$-CIA mice compared to male normal and male WT-CIA mice (Fig. 5, black arrows). Taken together, these results suggest that both female and male $\mathrm{PR}^{\Delta \mathrm{Prx} 1}$ mice developed more severe 
a

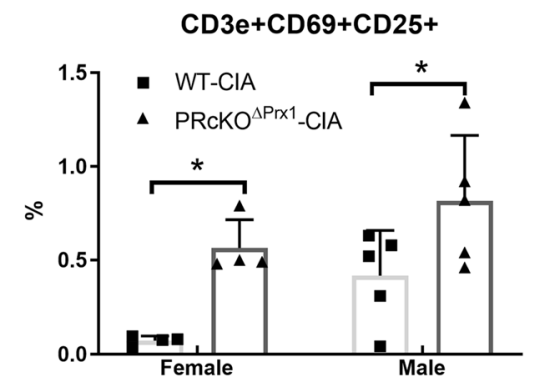

b

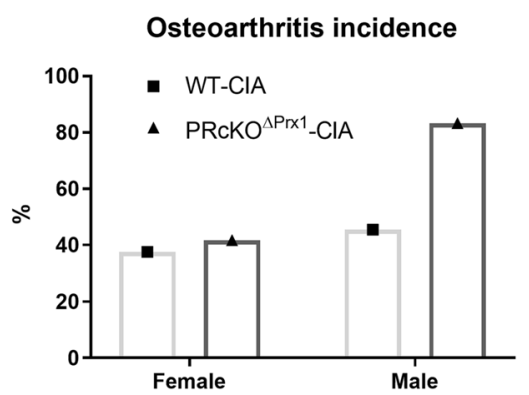

Fig. 1 Mice with PR conditionally knocked out in osteoprogenitor cells had higher circulating T cells and higher arthritis incidence in male mice. (a) Mononuclear cells were obtained from peripheral blood in WT-CIA or PR ${ }^{\triangle P \text { rx }}$-CIA and subjected to FAC determination of CD3e+, CD69+, and CD25+ T-cells. (b) The incidence of arthritis was scored using 3D images of paws showing bone erosion at least in one of the paws. ${ }^{*} p<0.05$ between indicated groups

bone loss in the knee joints. The male $\mathrm{PR}^{\Delta \mathrm{Prx} 1}$ mice are more susceptible to bone loss in the paw and developed higher bone erosion in the knee joints compared to their sex-matched WT-CIA mice.

\section{Male $\mathrm{PR}^{\Delta \mathrm{Prx} 1}$ mice with collagen-induced arthritis had more cartilage damage than WT-CIA control}

Cartilage destruction and inflammation were assessed on H\&E- and Safranin-O-stained sections. The overall semi-quantitative scoring on the H\&E-stained sections revealed more inflammation and erosions in the male $\mathrm{PR}^{\Delta \operatorname{Prx} 1}$-CIA mice compared to WT-CIA mice (Fig. 6). Examination of Safranin-O-stained knee samples revealed a loss of articular cartilage, especially in the male CIA mice (Fig. 4a, b). In the male $\mathrm{PR}^{\Delta \operatorname{Prx} 1}$-CIA mice, there was an almost complete loss of articular cartilage in areas of subchondral bone erosion (Figs. 4 and 6). A similar area of subchondral bone erosion and articular cartilage loss was present in the male WT-CIA as well. Cartilage loss was noted adjacent to inflamed synovium tissues, especially in male $\mathrm{WT}$ and $\mathrm{PR}^{\triangle \mathrm{Prx} 1}$-CIA mice (Fig. 6a, b). The semi-quantitative erosion and cartilage damage scores were higher in the male $\mathrm{PR}^{\Delta \operatorname{Prx} 1}$-CIA mice than in the WT-CIA mice (Fig. 6c).

\section{Discussion}

Mice lacking progesterone receptor signaling in the osteoprogenitor cells were more susceptible to collageninduced arthritis, especially male mice. The $\mathrm{PR}^{\Delta \operatorname{Prx} 1}$-CIA mice, especially the males, had a significantly higher incidence of arthritis, joint inflammation, bone erosion, and cartilage damage compared to the normal male $\mathrm{PR}^{\triangle \mathrm{Prx} 1}$ mice or WT-CIA mice. Our findings indicate that under "normal" conditions, the presence of PR in osteoprogenitor cells might be protective against inflammatory arthritis and may also contribute to the sex differences that are observed in RA patients [53-55].
A number of susceptibility genes for RA have been previously identified. The human leukocyte antigen (HLA) is a genetic site controlling immune responses in RA [56, 57]. Several genes outside the HLA region, including Stat4, the TRAF1-C5 locus, and PTPN22, have been reported to be associated with activation and progression of inflammation in RA [58-62]. Sex disparities in genetic susceptibility to RA are understudied, and only a polymorphism in the $C y b 5 a$ gene, which is related to androgen synthesis, has been found to be associated with risk for RA in women but not in men [63]. Recent studies have also suggested a role for epigenetic modifications in the activation and aggressiveness of synovial fibroblasts [64-67] and the X-encoded genes, Timp1 and $I L-9 R$ in RA [68]. Some of these epigenetic modifications correlate with X-linked miRNA, and the presence of the second $\mathrm{X}$ chromosome in females may affect miRNA expression levels, potentially helping to explain sex-related autoimmunity [69, 70]. Most of these studies on sex-specific factors affecting RA have focused on the potential effects of sex hormones due to the observation that RA improves during pregnancy and that male RA patients generally have a less severe course of illness and better response to therapy $[5,9,10]$. Estrogen has been reported to have both pro-inflammatory and antiinflammatory effects on the immune system while both progesterone and androgen are anti-inflammatory [11-19]. The effects of hormones are mainly regulated through their hormonal receptors. The presence and proportion of estrogen and androgen receptors in different tissues and cells, including fibroblasts, chondrocytes, and bone cells, might define their roles in the sexually dimorphic pathogenesis of RA [20-27]. We and others have found PR expressed in growth plate chondrocytes, osteoclasts, and osteoblasts, and PR has a critical role in peak bone mass determination in mice $[37,71,72]$. Loss of PR signaling in osteoprogenitor cells regulates key signaling pathways for immune response, especially in males [34]. We identified PR-targeted 


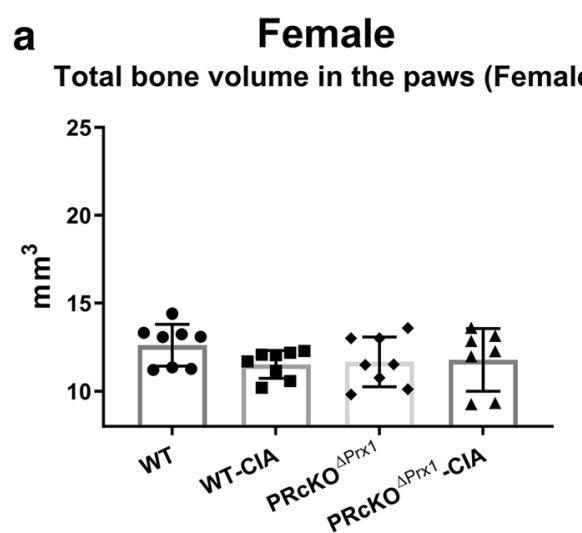

Male

b

Female

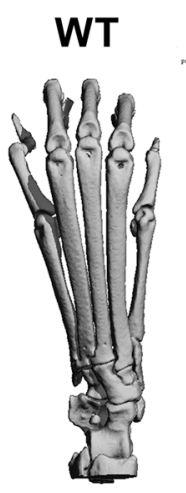

WT-CIA

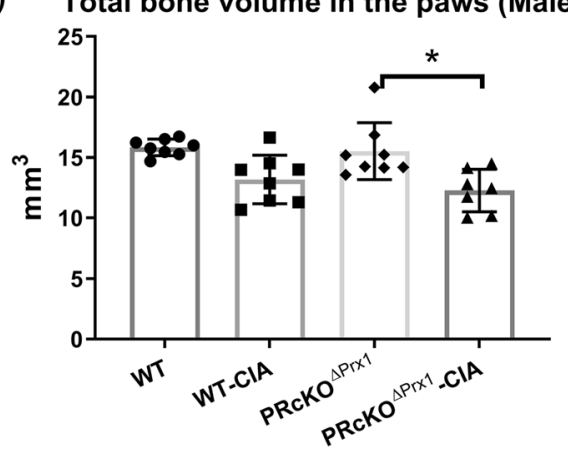

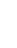
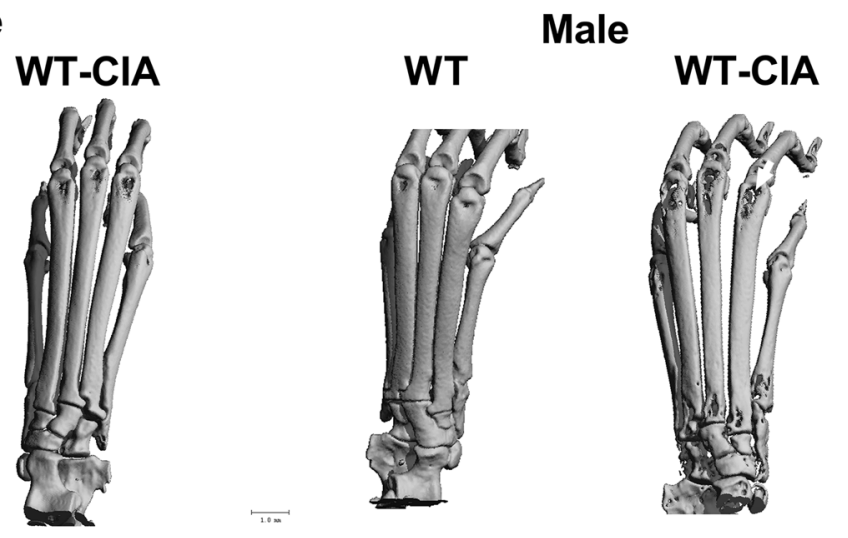

Male

KO

KO-CIA
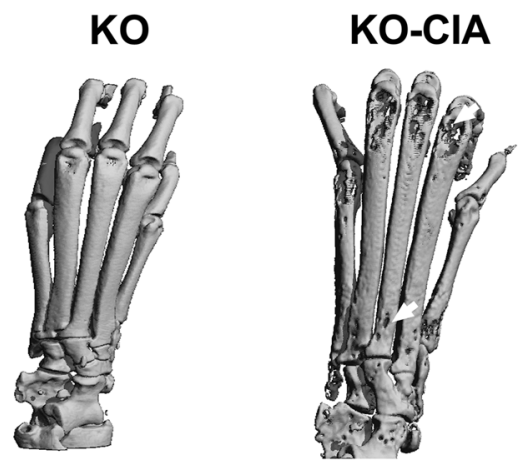

Fig. 2 Mice with PR conditionally knocked out in osteoprogenitor cells had a lower bone mass in the paws of male PR ${ }^{\Delta \mathrm{Prx}}$-CIA mice. (a) The total bone volume of the right paws was measured by microCT in WT and PR ${ }^{\Delta P r x}$ normal or CIA mice. (b) Representative microCT paw images from $\mathrm{WT}$ or $\mathrm{PR}^{\Delta \mathrm{Prx} 1}$ normal or CIA mice. White arrows illustrated bone erosion. ${ }^{*} p<0.05$ between indicated groups. Scale bar $=1 \mathrm{~mm}$

genes that regulated sex differences, including an "X-inactive specific transcript," Xist, Mtus2, Aldhla7/1, Tusc5, $C d 300 c$, and Pde $3 a$ [34]. The upregulation of Xist is associated with chronic inflammation and pain in females with complex regional pain syndrome [73] and contributes to RA progression [74]. Cd300c and Pde3a are overpresented in RA patients [75, 76] and are associated with inhibition of $\mathrm{T}$ cell immunity [77] or response to TNF inhibitors in RA patients [78]. Our prior and current findings
[34, 37, 39, 71] suggest that PR may regulate susceptibility to inflammatory arthritis in mice.

The presence of marginal bone erosions, detected by imaging, predicts a more severe disease course with more disability and increased morbidity. The significance of erosions in RA has been the focus of the development and approval of several agents for modifying the course of RA and has been validated in clinical trials as being able to reduce structural joint damage, including bone erosion and 

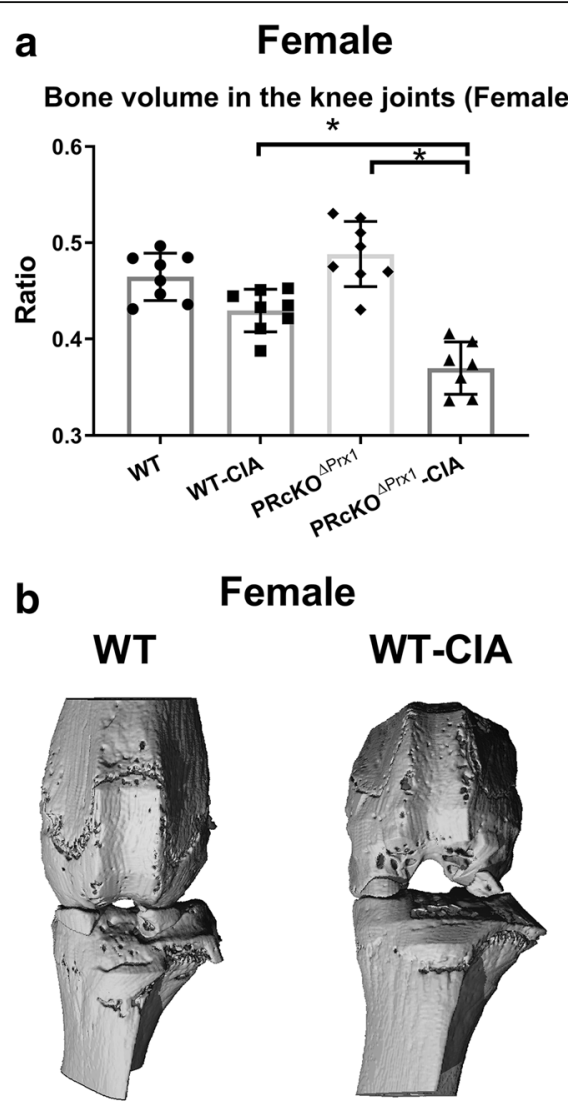

Female

KO

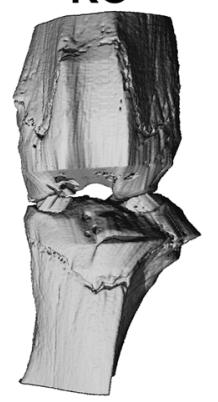

WT-CIA

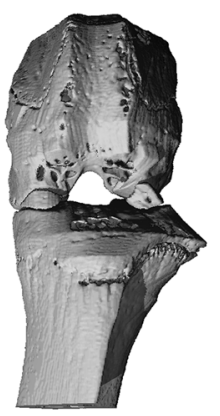

KO-CIA

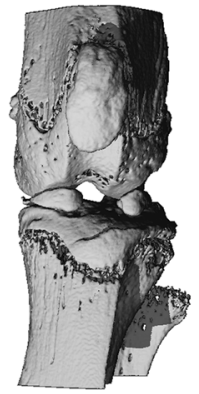

Male

Bone volume in the knee joints (Male)

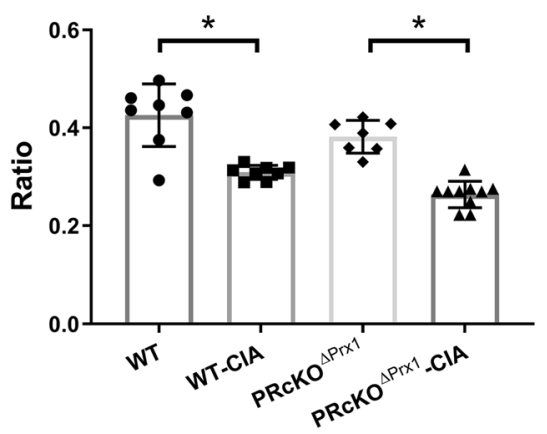

Male
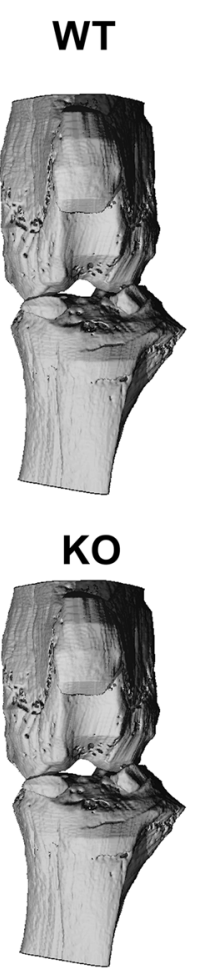

\section{WT-CIA}

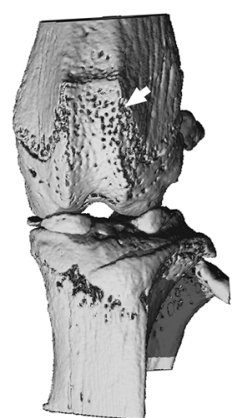

\section{KO-CIA}

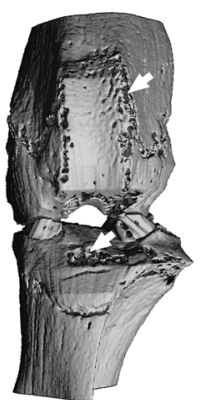

Fig. 3 Mice with PR conditionally knocked out in osteoprogenitor cells had a lower bone mass in the knee joints of PR ${ }^{\Delta P r x}$-CIA mice. (a) Total bone volume/tissue volume of right knees was measured by microCT in WT and PR ${ }^{\Delta \mathrm{Prx} 1}$ normal or CIA mice. (b) Representative microCT knee images from WT or $P R^{\Delta P r x 1}$ normal or ClA mice. White arrows indicated bone erosions. ${ }^{*} p<0.05$ between indicated groups

cartilage degradation $[79,80]$. The bone erosions in RA show a predilection for specific anatomic sites such as the radial aspects of finger joints, while the ulnar aspects are relatively spared [81]. These focal erosions typically emerge at the site at which the synovium comes into direct contact with the bone which is known as bare areas. Anatomical factors that predispose these skeletal sites for erosion include the presence of mineralized cartilage, the insertion of ligaments at the bone surface, and inflamed tendon sheaths that enable the spread of inflammation from the tendon to the articular synovium. Articular erosion at these "bare areas" represents localized bone loss from osteolysis, which resulted from an imbalance in which bone resorption by osteoclasts is predominant over bone formation by osteoblasts. Once established, these bone erosions rarely repair despite the use of potent biologic therapeutic strategies including biologics such as TNF, IL-1, or IL-6 receptor blockade [82-85]. Aberrant repair of erosions appeared as sclerosis with new bone apposition at the base of the erosion and might involve the juxta-articular bone marrow. Adipose tissue might populate the erosive area. Bone erosion seemed to correlate 


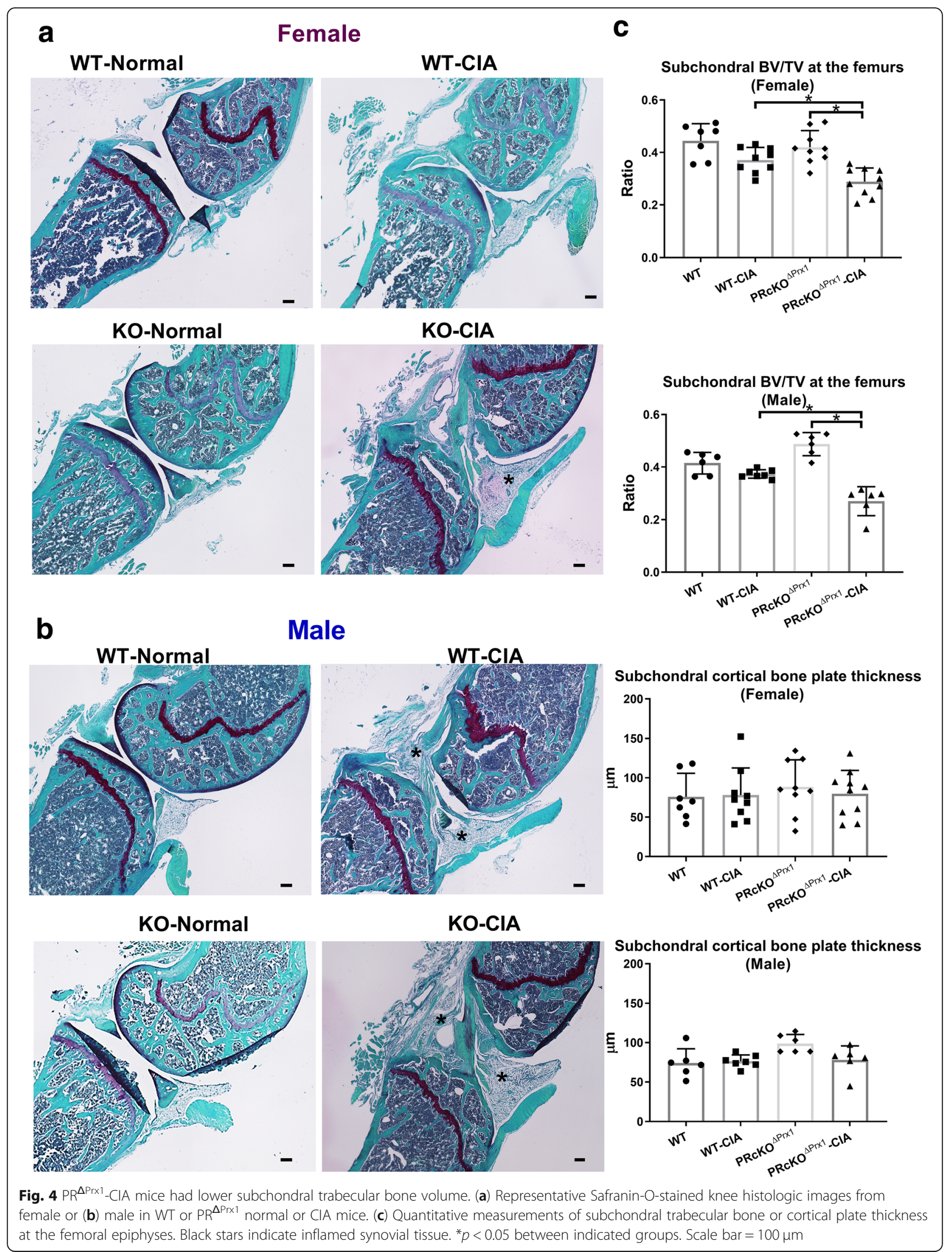




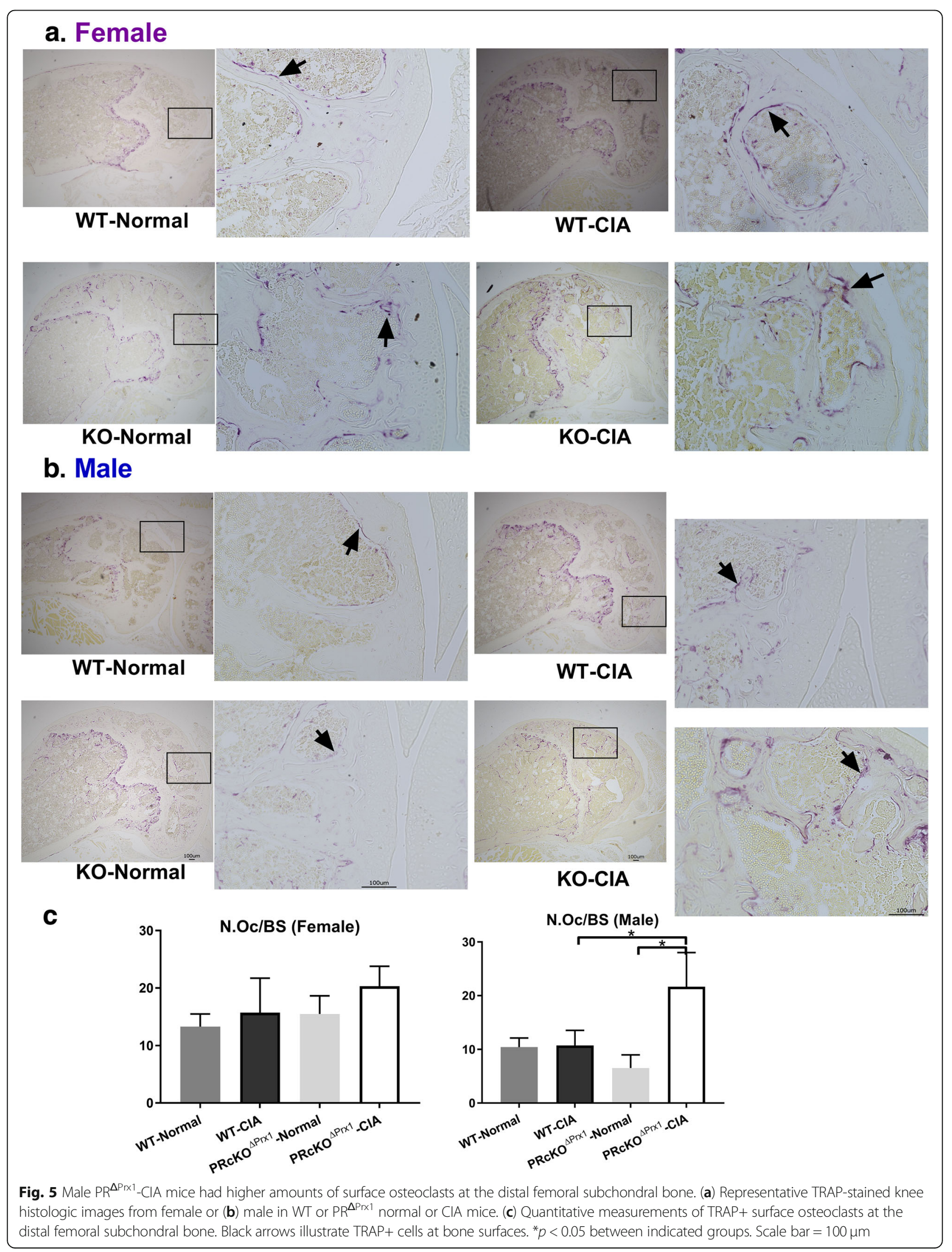




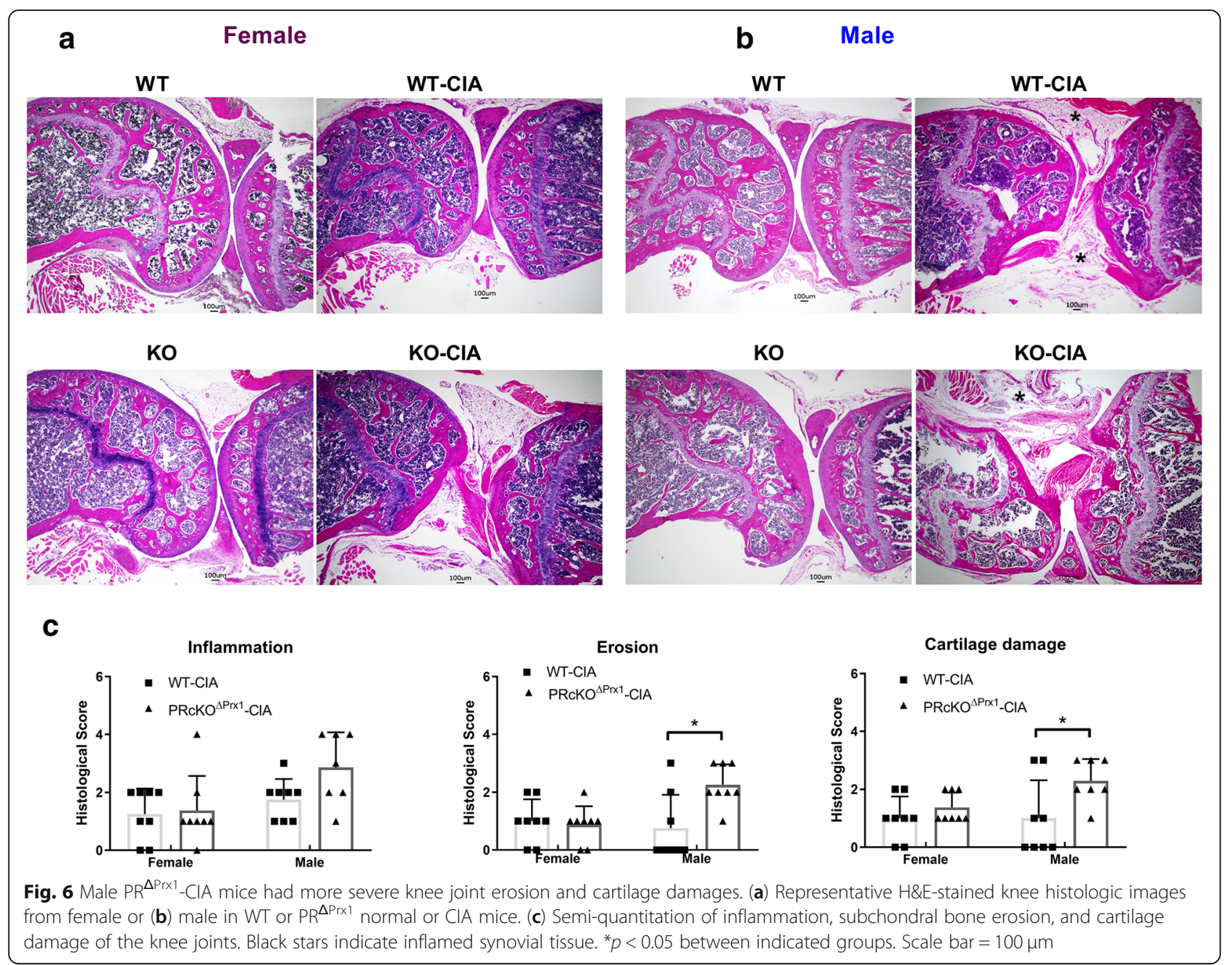

with on-going inflammation. Our study provides additional information to better understand the potential PR regulation of the inflammation-induced bone resorption coupling mechanism in the process of joint and bone damage and how potentiation of this coupling from lack of PR signaling contributes to bone and joint tissue loss in RA in a sex-dependent manner.

RA is a systemic autoimmune disease that induces inflammation of the synovial tissue and causes activation of inflammatory cytokines that destroy both cartilage and peri-articular bone. One of the main shortcomings for the study was the lack of measurements of cytokines and chemokines systemically or locally in the joint tissue. Therefore, we could not directly determine if the PR regulation of joint inflammation and bone loss were directly associated with changes in the cytokine/chemokine levels during the pathogenesis of IA or with the lack of PR expression in the osteoprogenitor cells. Nevertheless, our data suggested that PR might alter the susceptibility to inflammation, cartilage damage, and bone destruction in RA.

\section{Conclusions}

In conclusion, lack of PR in osteoprogenitor cells increased susceptibility to IA, especially in male mice. Our findings indicate that the presence of PR in osteoprogenitor cells decreases the development of collageninduced arthritis and might also help to explain sex differences observed in rheumatoid arthritis.

\section{Acknowledgements}

PR-flox mouse was obtained from Dr. John Lydon at Baylor College of Medicine.

\section{Authors' contributions}

LL and JJ: study conception and design, collection and assembly of data, data analysis and interpretation, manuscript writing, and final approval of the manuscript. MJ, XPL, and CLD: collection and assembly of data, data analysis, interpretation, and final approval of the manuscript. BLW: data analysis, interpretation of the results, editing of drafts, and final approval of the manuscript. NEL: data interpretation, editing of manuscript, and final 
approval of the manuscript. WY: conception and design, collection and assembly of data, data analysis and interpretation, manuscript writing, and final approval of the manuscript.

\section{Funding}

NIH/NIAMS 1P50AR063043 (NEL main Pl; WY, project PI) and UC Davis School of Medicine Bridging fund (WY), and an award provided to the distinguish professors by Guanxi Medical University (WY).

\section{Availability of data and materials}

The datasets used and/or analyzed during the current study are available from the corresponding author on reasonable request.

\section{Ethics approval and consent to participate}

The animal studies were approved by UC Davis IACUC under protocol \#20064.

\section{Consent for publication}

The data presented in this manuscript have not been submitted or published elsewhere.

\section{Competing interests}

The authors declare that they have no competing interests.

\section{Author details}

'Department of Internal Medicine, University of California, Davis Medica Center, 4625 2nd Avenue, Sacramento, CA 95817, USA. ${ }^{2}$ Faculty of Animal Science and Technology, Yunnan Agricultural University, Kunming, Yunnan, People's Republic of China. ${ }^{3}$ Department of Orthopaedic Surgery, UC Davis Medical Center, Sacramento 95817, USA.

Received: 11 March 2020 Accepted: 9 June 2020

Published online: 02 July 2020

\section{References}

1. Garnero P, Thompson E, Woodworth T, Smolen JS. Rapid and sustained improvement in bone and cartilage turnover markers with the antiinterleukin-6 receptor inhibitor tocilizumab plus methotrexate in rheumatoid arthritis patients with an inadequate response to methotrexate: results from a substudy of the multicenter double-blind, placebo-controlled trial of tocilizumab in inadequate responders to methotrexate alone. Arthritis Rheum. 2010;62(1):33-43

2. Mansson B, Gulfe A, Geborek P, Heinegard D, Saxne T. Release of cartilage and bone macromolecules into synovial fluid: differences between psoriatic arthritis and rheumatoid arthritis. Ann Rheum Dis. 2001;60(1):27-31.

3. Mansson B, Carey D, Alini M, lonescu M, Rosenberg LC, Poole AR, Heinegard D, Saxne T. Cartilage and bone metabolism in rheumatoid arthritis. Differences between rapid and slow progression of disease identified by serum markers of cartilage metabolism. J Clin Invest. 1995;95(3):1071-7.

4. Morgacheva O, Furst DE. Women are from venus, men are from Mars: do gender differences also apply to rheumatoid arthritis activity and treatment responses? J Clin Rheumatol. 2012;18(5):259-60.

5. Sokka T, Toloza S, Cutolo M, Kautiainen H, Makinen H, Gogus F, Skakic V, Badsha $\mathrm{H}$, Peets $\mathrm{T}$, Baranauskaite $\mathrm{A}$, et al. Women, men, and rheumatoid arthritis: analyses of disease activity, disease characteristics, and treatments in the QUEST-RA study. Arthritis Res Ther. 2009;11(1):R7.

6. Hallert E, Thyberg I, Hass U, Skargren E, Skogh T. Comparison between women and men with recent onset rheumatoid arthritis of disease activity and functional ability over two years (the TIRA project). Ann Rheum Dis. 2003:62(7):667-70.

7. Katz PP, Criswell LA. Differences in symptom reports between men and women with rheumatoid arthritis. Arthritis Care Res. 1996:9(6):441-8.

8. Srikanth VK, Fryer JL, Zhai G, Winzenberg TM, Hosmer D, Jones G. A metaanalysis of sex differences prevalence, incidence and severity of osteoarthritis. Osteoarthr Cartil. 2005;13(9):769-81.

9. Forger F, Marcoli N, Gadola S, Moller B, Villiger PM, Ostensen M. Pregnancy induces numerical and functional changes of CD4+CD25 high regulatory cells in patients with rheumatoid arthritis. Ann Rheum Dis. 2008;67(7):984-90.

10. Ostensen $M$, Villiger PM. The remission of rheumatoid arthritis during pregnancy. Semin Immunopathol. 2007;29(2):185-91.
11. Castagnetta LA, Carruba G, Granata OM, Stefano R, Miele M, Schmidt M, Cutolo M, Straub RH. Increased estrogen formation and estrogen to androgen ratio in the synovial fluid of patients with rheumatoid arthritis. $J$ Rheumatol. 2003:30(12):2597-605.

12. Cutolo M. Estrogen metabolites: increasing evidence for their role in rheumatoid arthritis and systemic lupus erythematosus. J Rheumatol. 2004;31(3):419-21.

13. Merlino LA, Cerhan JR, Criswell LA, Mikuls TR, Saag KG. Estrogen and other female reproductive risk factors are not strongly associated with the development of rheumatoid arthritis in elderly women. Semin Arthritis Rheum. 2003;33(2):72-82.

14. Schmidt M, Weidler C, Naumann H, Anders S, Scholmerich J, Straub RH. Androgen conversion in osteoarthritis and rheumatoid arthritis synoviocytes-androstenedione and testosterone inhibit estrogen formation and favor production of more potent 5alpha-reduced androgens. Arthritis Res Ther. 2005;7(5):R938-48.

15. Yamaguchi A, Nozawa K, Fujishiro M, Kawasaki M, Takamori K, Ogawa H, Sekigawa I, Takasaki Y. Estrogen inhibits apoptosis and promotes CC motif chemokine ligand 13 expression on synovial fibroblasts in rheumatoid arthritis. Immunopharmacol Immunotoxicol. 2012;34(5):852-7.

16. Cuchacovich $M$, Tchernitchin A, Gatica $H$, Wurgaft $R$, Valenzuela C, Cornejo E. Intraarticular progesterone: effects of a local treatment for rheumatoid arthritis. J Rheumatol. 1988;15(4):561-5.

17. Khalkhali-Ellis Z, Seftor EA, Nieva DR, Handa RJ, Price RH Jr, Kirschmann DA, Baragi VM, Sharma RV, Bhalla RC, Moore TL, et al. Estrogen and progesterone regulation of human fibroblast-like synoviocyte function in vitro: implications in rheumatoid arthritis. J Rheumatol. 2000;27(7):1622-31.

18. Karlson EW, Chibnik LB, McGrath M, Chang SC, Keenan BT, Costenbader KH, Fraser PA, Tworoger S, Hankinson SE, Lee IM, et al. A prospective study of androgen levels, hormone-related genes and risk of rheumatoid arthritis. Arthritis Res Ther. 2009;11(3):R97.

19. Su L, Sun Y, Ma F, Lu P, Huang H, Zhou J. Progesterone inhibits Toll-like receptor 4mediated innate immune response in macrophages by suppressing NF-kappaB activation and enhancing SOCS1 expression. Immunol Lett. 2009:125(2):151-5.

20. Caggiano TJ, Brazzale A, Ho DM, Kraml CM, Trybulski E, Chadwick CC, Chippari S, Borges-Marcucci L, Eckert A, Keith JC, et al. Estrogen receptor dependent inhibitors of NF-kappaB transcriptional activation-1 synthesis and biological evaluation of substituted 2-cyanopropanoic acid derivatives: pathway selective inhibitors of NF-kappaB, a potential treatment for rheumatoid arthritis. J Med Chem. 2007:50(22):5245-8.

21. Gonzalez-Canga A, Ugai K, Suzuki M, Okuzawa H, Negishi E, Ueno K. Association of cytosine-adenine repeat polymorphism of the estrogen receptor-beta gene with rheumatoid arthritis symptoms. Rheumatol Int. 2010;30(9):1259-62.

22. Masi L, Maddali Bongi S, Angotti C, Del Monte F, Carbonell Sala S, Basetti M, Amedei A, Falchetti A, Brandi ML. The role of osteoprotegerin (OPG) and estrogen receptor (ER-alpha) gene polymorphisms in rheumatoid arthritis. Clin Cases Miner Bone Metab. 2007:4(2):156-60.

23. Sato H, Ito A, Gonzalez-Canga A, Okuzawa H, Ugai K, Suzuki M, Namiki T, Ueno K. Association of Rsa polymorphism of the estrogen receptor-beta gene with rheumatoid arthritis. Rheumatol Int. 2012;32(7):2143-8.

24. Schmidt M, Hartung R, Capellino S, Cutolo M, Pfeifer-Leeg A, Straub RH. Estrone/17beta-estradiol conversion to, and tumor necrosis factor inhibition by, estrogen metabolites in synovial cells of patients with rheumatoid arthritis and patients with osteoarthritis. Arthritis Rheum. 2009;60(10):2913-22.

25. Cutolo M, Accardo S, Villaggio B, Clerico P, Indiveri F, Carruba G, Fecarotta E, Castagnetta L. Evidence for the presence of androgen receptors in the synovial tissue of rheumatoid arthritis patients and healthy controls. Arthritis Rheum. 1992; 35(9):1007-15.

26. Khalkhali-Ellis Z, Handa RJ, Price RH Jr, Adams BD, Callaghan JJ, Hendrix MJ. Androgen receptors in human synoviocytes and androgen regulation of interleukin 1beta (IL-1beta) induced IL-6 production: a link between hypoandrogenicity and rheumatoid arthritis? J Rheumatol. 2002;29(9):1843-6.

27. Lo SF, Huang CM, Tsai CH, Chen WC, Lai CC, Tsai Y, Tsai FJ. Androgen receptor gene polymorphism and rheumatoid arthritis in Taiwan. Clin Exp Rheumatol. 2006; 24(2):209-10

28. Conneely OM, Lydon JP. Progesterone receptors in reproduction: functional impact of the A and B isoforms. Steroids. 2000;65(10-11):571-7.

29. Quadros PS, Goldstein AY, De Vries GJ, Wagner CK. Regulation of sex differences in progesterone receptor expression in the medial preoptic nucleus of postnatal rats. J Neuroendocrinol. 2002:14(10):761-7.

30. Singh S, Sheppard MC, Langman MJ. Sex differences in the incidence of colorectal cancer: an exploration of oestrogen and progesterone receptors. Gut. 1993;34(5):611-5. 
31. Ojanotko A, Mielityinen $H$, Harri MP. Progesterone metabolism by rat oral mucosa. I Sex differences. J Periodontal Res. 1981;16(5):490-6.

32. Hughes GC. Progesterone and autoimmune disease. Autoimmun Rev. 2012; 11(6-7):A502-14

33. Yates MA, Li Y, Chlebeck P, Proctor T, Vandenbark AA, Offner $H$. Progesterone treatment reduces disease severity and increases IL-10 in experimental autoimmune encephalomyelitis. J Neuroimmunol. 2010;220(12):136-9.

34. Kot A, Zhong ZA, Zhang H, Lay YE, Lane NE, Yao W. Sex dimorphic regulation of osteoprogenitor progesterone in bone stromal cells. J Mol Endocrinol. 2017:59(4):351-63.

35. Wei LL, Leach MW, Miner RS, Demers LM. Evidence for progesterone receptors in human osteoblast-like cells. Biochem Biophys Res Commun. 1993;195(2):525-32.

36. MacNamara P, O'Shaughnessy C, Manduca P, Loughrey HC. Progesterone receptors are expressed in human osteoblast-like cell lines and in primary human osteoblast cultures. Calcif Tissue Int. 1995;57(6):436-41.

37. Yao W, Dai W, Shahnazari M, Pham A, Chen Z, Chen H, Guan M, Lane NE. Inhibition of the progesterone nuclear receptor during the bone linear growth phase increases peak bone mass in female mice. PLoS One. 2010; 5(7):e11410.

38. Wang W, Hayami T, Kapila S. Female hormone receptors are differentially expressed in mouse fibrocartilages. Osteoarthr Cartil. 2009;17(5):646-54.

39. Zhong ZA, Kot A, Lay YE, Zhang H, Jia J, Lane NE, Yao W. Sex-dependent, osteoblast stage-specific effects of progesterone receptor on bone acquisition. J Bone Miner Res. 2017;32(9):1841-52.

40. Fernandez-Valdivia R, Jeong J, Mukherjee A, Soyal SM, Li J, Ying Y, Demayo FJ, Lydon JP. A mouse model to dissect progesterone signaling in the female reproductive tract and mammary gland. Genesis. 2010:48(2):106-13.

41. Woods AM, Thompson SJ, Wooley PH, Panayi G, Klavinskis LS. Immune modulation of collagen-induced arthritis by intranasal cytokine gene delivery: a model for the therapy of rheumatoid arthritis. Arthritis Rheum. 2005;52(12):3761-71

42. Augello A, Tasso R, Negrini SM, Cancedda R, Pennesi G. Cell therapy using allogeneic bone marrow mesenchymal stem cells prevents tissue damage in collagen-induced arthritis. Arthritis Rheum. 2007;56(4):1175-86.

43. Seeuws $S$, Jacques $P$, Van Praet J, Drennan M, Coudenys J, Decruy $T$, Deschepper $\mathrm{E}$, Lepescheux L, Pujuguet $\mathrm{P}$, Oste $\mathrm{L}$, et al. A multiparameter approach to monitor disease activity in collagen-induced arthritis. Arthritis Res Ther. 2010;12(4):R160.

44. Trentham DE, Townes AS, Kang AH. Autoimmunity to type II collagen an experimental model of arthritis. J Exp Med. 1977;146(3):857-68.

45. Courtenay JS, Dallman MJ, Dayan AD, Martin A, Mosedale B. Immunisation against heterologous type II collagen induces arthritis in mice. Nature. 1980; 283(5748):666-8.

46. Corr M, Boyle DL, Ronacher LM, Lew BR, van Baarsen LG, Tak PP, Firestein GS. Interleukin 1 receptor antagonist mediates the beneficial effects of systemic interferon beta in mice: implications for rheumatoid arthritis. Ann Rheum Dis. 2011;70(5):858-63.

47. Kyburz D, Corr M. The KRN mouse model of inflammatory arthritis. Springer Semin Immunopathol. 2003;25(1):79-90.

48. Choe JY, Crain B, Wu SR, Corr M. Interleukin 1 receptor dependence of serum transferred arthritis can be circumvented by toll-like receptor 4 signaling. J Exp Med. 2003;197(4):537-42.

49. Douni E, Sfikakis PP, Haralambous S, Fernandes P, Kollias G. Attenuation of inflammatory polyarthritis in TNF transgenic mice by diacerein: comparative analysis with dexamethasone, methotrexate and anti-TNF protocols. Arthritis Res Ther. 2004;6(1):R65-72.

50. Pettit AR, Ji H, von Stechow D, Muller R, Goldring SR, Choi Y, Benoist C, Gravallese EM. TRANCE/RANKL knockout mice are protected from bone erosion in a serum transfer model of arthritis. Am J Pathol. 2001;159(5): 1689-99.

51. Zhen G, Wen C, Jia X, Li Y, Crane JL, Mears SC, Askin FB, Frassica FJ, Chang W, Yao J, et al. Inhibition of TGF-beta signaling in mesenchymal stem cells of subchondral bone attenuates osteoarthritis. Nat Med. 2013;19(6):704-12.

52. Cui Z, Crane J, Xie H, Jin X, Zhen G, Li C, Xie L, Wang L, Bian Q, Qiu T, et al. Halofuginone attenuates osteoarthritis by inhibition of TGF-beta activity and H-type vessel formation in subchondral bone. Ann Rheum Dis. 2016;75(9):1714-21.

53. Jawaheer D, Lum RF, Gregersen PK, Criswell LA. Influence of male sex on disease phenotype in familial rheumatoid arthritis. Arthritis Rheum. 2006; 54(10):3087-94.
54. Weyand CM, Schmidt D, Wagner U, Goronzy JJ. The influence of sex on the phenotype of rheumatoid arthritis. Arthritis Rheum. 1998;41(5):817-22.

55. Whitacre CC. Sex differences in autoimmune disease. Nat Immunol. 2001; 2(9):777-80.

56. McMichael AJ, Sasazuki T, McDevitt HO, Payne RO. Increased frequency of HLA-Cw3 and HLA-Dw4 in rheumatoid arthritis. Arthritis Rheum. 1977;20(5): 1037-42.

57. Okada Y, Wu D, Trynka G, Raj T, Terao C, Ikari K, Kochi Y, Ohmura K, Suzuki A, Yoshida S, et al. Genetics of rheumatoid arthritis contributes to biology and drug discovery. Nature. 2014;506(7488):376-81.

58. Watford WT, Hissong BD, Bream JH, Kanno Y, Muul L, O'Shea JJ. Signaling by IL-12 and IL-23 and the immunoregulatory roles of STAT4. Immunol Rev. 2004;202:139-56.

59. Remmers EF, Plenge RM, Lee AT, Graham RR, Hom G, Behrens TW, de Bakker PI, Le JM, Lee HS, Batliwalla F, et al. STAT4 and the risk of rheumatoid arthritis and systemic lupus erythematosus. N Engl J Med. 2007; 357(10):977-86

60. Plenge RM, Seielstad M, Padyukov L, Lee AT, Remmers EF, Ding B, Liew A, Khalili H, Chandrasekaran A, Davies LR, et al. TRAF1-C5 as a risk locus for rheumatoid arthritis--a genomewide study. N Engl J Med. 2007;357(12): 1199-209.

61. Begovich AB, Carlton VE, Honigberg LA, Schrodi SJ, Chokkalingam AP, Alexander HC, Ardlie KG, Huang Q, Smith AM, Spoerke JM, et al. A missense single-nucleotide polymorphism in a gene encoding a protein tyrosine phosphatase (PTPN22) is associated with rheumatoid arthritis. Am J Hum Genet. 2004;75(2):330-7.

62. Kyogoku C, Langefeld CD, Ortmann WA, Lee A, Selby S, Carlton VE, Chang M, Ramos P, Baechler EC, Batliwalla FM, et al. Genetic association of the R620W polymorphism of protein tyrosine phosphatase PTPN22 with human SLE. Am J Hum Genet. 2004;75(3):504-7.

63. Stark K, Straub RH, Rovensky J, Blazickova S, Eiselt G, Schmidt M. CYB5A polymorphism increases androgens and reduces risk of rheumatoid arthritis in women. Arthritis Res Ther. 2015;17:56.

64. Angiolilli C, Grabiec AM, Ferguson BS, Ospelt C, Malvar Fernandez B, van Es IE, van Baarsen LG, Gay S, McKinsey TA, Tak PP, et al. Inflammatory cytokines epigenetically regulate rheumatoid arthritis fibroblast-like synoviocyte activation by suppressing HDAC5 expression. Ann Rheum Dis. 2016;75(2):430-8.

65. Filkova M, Aradi B, Senolt L, Ospelt C, Vettori S, Mann H, Filer A, Raza K, Buckley CD, Snow M, et al. Association of circulating miR-223 and miR-16 with disease activity in patients with early rheumatoid arthritis. Ann Rheum Dis. 2014;73(10):1898-904

66. Karouzakis E, Trenkmann M, Gay RE, Michel BA, Gay S, Neidhart M. Epigenome analysis reveals TBX5 as a novel transcription factor involved in the activation of rheumatoid arthritis synovial fibroblasts. J Immunol. 2014; 193(10):4945-51.

67. Neidhart M, Karouzakis E, Jungel A, Gay RE, Gay S. Inhibition of spermidine/ spermine N1-acetyltransferase activity: a new therapeutic concept in rheumatoid arthritis. Arthritis Rheumatol. 2014;66(7):1723-33.

68. Burkhardt J, Petit-Teixeira E, Teixeira VH, Kirsten H, Garnier S, Ruehle S, Oeser C, Wolfram G, Scholz M, Migliorini P, et al. Association of the Xchromosomal genes TIMP1 and IL9R with rheumatoid arthritis. J Rheumatol. 2009;36(10):2149-57.

69. Khan D, Dai $R$, Ansar Ahmed $S$. Sex differences and estrogen regulation of miRNAs in lupus, a prototypical autoimmune disease. Cell Immunol. 2015;294(2):70-9.

70. Pinheiro I, Dejager L, Libert C. X-chromosome-located microRNAs in immunity: might they explain male/female differences? The $X$ chromosomegenomic context may affect $X$-located miRNAs and downstream signaling, thereby contributing to the enhanced immune response of females. Bioessays. 2011:33(11):791-802.

71. Zhong ZA, Sun W, Chen H, Zhang H, Lane NE, Yao W. Inactivation of the progesterone receptor in $\mathrm{M} \times 1+$ cells potentiates osteogenesis in calvaria but not in long bone. PLoS One. 2015;10(10):e0139490.

72. Rickard DJ, Iwaniec UT, Evans G, Hefferan TE, Hunter JC, Waters KM, Lydon JP, O'Malley BW, Khosla S, Spelsberg TC, et al. Bone growth and turnover in progesterone receptor knockout mice. Endocrinology. 2008;149(5):2383-90.

73. Shenoda BB, Tian Y, Alexander GM, Aradillas-Lopez E, Schwartzman RJ. Ajit SK: miR-34a-mediated regulation of XIST in female cells under inflammation. J Pain Res. 2018;11:935-45.

74. Li G-Q, Fang Y-X, Liu Y, Meng F-R, Wu X, Zhang C-W, Zhang Y, Liu Y-Q, Liu $D$. Long noncoding RNA XIST binding to Let-7c-5p contributes to rheumatoid arthritis through its effects on proliferation and differentiation 
of osteoblasts via regulation of STAT3. EBioMedicine 2019. https://doi.org/ 10.2139/ssin.3343639.

75. Del Rey MJ, Izquierdo E, Usategui A, Gonzalo E, Blanco FJ, Acquadro F, Pablos JL. The transcriptional response of normal and rheumatoid arthritis synovial fibroblasts to hypoxia. Arthritis Rheum. 2010;62(12):3584-94.

76. Acosta-Colman I, Palau N, Tornero J, Fernandez-Nebro A, Blanco F, Gonzalez-Alvaro I, Canete JD, Maymo J, Ballina J, Fernandez-Gutierrez B, et al. GWAS replication study confirms the association of PDE3A-SLCO1C1 with anti-TNF therapy response in rheumatoid arthritis. Pharmacogenomics. 2013;14(7):727-34.

77. Cui C, Su M, Lin Y, Lai L. A CD300c-fc fusion protein inhibits T cell immunity. Front Immunol. 2018;9:2657.

78. Lopez-Rodriguez R, Perez-Pampin E, Marquez A, Blanco FJ, Joven B, Carreira $P$, Ferrer MA, Caliz R, Valor L, Narvaez J, et al. Validation study of genetic biomarkers of response to TNF inhibitors in rheumatoid arthritis. PLoS One. 2018;13(5):e0196793.

79. Dimitroulas T, Nikas SN, Trontzas P, Kitas GD. Biologic therapies and systemic bone loss in rheumatoid arthritis. Autoimmun Rev. 2013;12(10): 958-66.

80. Corrado A, Neve A, Maruotti N, Cantatore FP. Bone effects of biologic drugs in rheumatoid arthritis. Clin Dev Immunol. 2013;2013:945945.

81. Wakefield RJ, Gibbon WW, Conaghan PG, O'Connor P, McGonagle D, Pease C, Green MJ, Veale DJ, Isaacs JD, Emery P. The value of sonography in the detection of bone erosions in patients with rheumatoid arthritis: a comparison with conventional radiography. Arthritis Rheum. 2000;43(12): 2762-70.

82. Caramaschi P, Biasi D, Colombatti M, Pieropan S, Martinelli N, Carletto A, Volpe A, Pacor LM, Bambara LM. Anti-TNFalpha therapy in rheumatoid arthritis and autoimmunity. Rheumatol Int. 2006;26(3):209-14.

83. Ferraccioli G, Gremese E. Thrombogenicity of TNF alpha in rheumatoid arthritis defined through biological probes: TNF alpha blockers. Autoimmun Rev. 2004;3(4):261-6.

84. Rech J, Ronneberger M, Englbrecht M, Finzel S, Katzenbeisser J, Manger K, Manger B, Schett G. Successful treatment of adult-onset Still's disease refractory to TNF and IL-1 blockade by IL-6 receptor blockade. Ann Rheum Dis. 2011;70(2):390-2.

85. Hashizume M, Tan SL, Takano J, Ohsawa K, Hasada I, Hanasaki A, Ito I, Mihara M, Nishida K. Tocilizumab, a humanized anti-LL-6R antibody, as an emerging therapeutic option for rheumatoid arthritis: molecular and cellular mechanistic insights. Int Rev Immunol. 2015;34(3):265-79.

\section{Publisher's Note}

Springer Nature remains neutral with regard to jurisdictional claims in published maps and institutional affiliations.

Ready to submit your research? Choose BMC and benefit from:

- fast, convenient online submission

- thorough peer review by experienced researchers in your field

- rapid publication on acceptance

- support for research data, including large and complex data types

- gold Open Access which fosters wider collaboration and increased citations

- maximum visibility for your research: over $100 \mathrm{M}$ website views per year

At $\mathrm{BMC}$, research is always in progress.

Learn more biomedcentral.com/submissions 